Institute of $\mathbf{F}_{\text {ood and }} \mathbf{A}$ gricultural $\mathbf{S}_{\text {ciences }}$

\title{
Proper Use of Organic Fertilizer Materials for Vegetable Crops Grown in Florida in the BMP Era ${ }^{1}$
}

\section{Eric Simonne and George Hochmuth ${ }^{2}$}

This publication is one of a series entitled Fertilizer and Irrigation Management in the BMP Era. This series is divided into nine principles described in the Introduction Chapter (HOS-897). This publication is part of Principle 2, "Soil Test and Follow the Recommendations." BMP implementation requires a global approach to production management. However, for presentation purposes, each aspect of vegetable production is described in a separate publication.

Waste organic by-products, including animal manures, composted organic matter, and sludges, contain nutrients that may enhance plant growth. These materials slowly decompose when applied to the soil, releasing nutrients for vegetable crops. The key to proper use of organic materials as fertilizers comes in the knowledge of the nutrient content, the $\mathrm{C}: \mathrm{N}$ ratio, and the decomposition rate of the materials. Many laboratories offer organic material analyses to determine specific nutrient contents. Decomposition rates of organic materials in warm sandy soils in Florida are rapid. Therefore, there will be relatively small amounts of residual nutrients remaining for succeeding crops. Organic materials are generally similar to mixed chemical fertilizers in that the organic waste supplies an array of nutrients, some of which may not be required on a particular soil.

Tables are available that describe the average nutrient concentration of animal wastes. However, the actual nutrient concentration of manures may vary from one livestock operation to another. Factors that contribute to this variation include: the number of animals per operation, composition of the feed, design of the waste management system, season of year, or animal health. Therefore, it is important that livestock wastes are sampled and analyzed to determine their nutrient concentrations before a sound, nutrient management plan can be designed, implemented, and maintained.

\section{Working Definition}

Organic or natural fertilizers are biosolids typically originating from bone meal, blood meal, crab waste compost, horse and chicken manure, mushroom compost, feathers, seaweed, bat droppings, ash from sunflower seed hulls, and variety of other substances that contain some essential elements and that provide organic matter to the soil.

1. This document is HS904, one of a series of the Horticultural Sciences Department, Florida Cooperative Extension Service, Institute of Food and Agricultural Sciences, University of Florida. Publication date: January 2003. Please visit the EDIS Web site at http://edis.ifas.ufl.edu.

2. Eric Simonne, assistant professor, George Hochmuth, center director, NFREC-Quincy, Horticultural Sciences Department, Cooperative Extension Service, Institute of Food and Agricultural Sciences, University of Florida, Gainesville, 32611. 


\section{Sampling - Things to Do}

- Take multiple samples and mix them so that the resulting composite sample is representative of the organic material.

- Sample should consist of a 1 quart freezer bag, labeled, and kept cool.

- Sample the organic material as near to the time of application as possible.

- Your local county extension office can assist you with this process and interpretation of results.

- Know the source and type if using sewage sludge. Certain classes of sludge are not appropriate for vegetable production and may not be permitted for land application.

\section{Application - Things to Do}

- Determine the organic materials nutrient content by having a laboratory analyze the material for its specific nutrient content.

- Base your application rate on the specific nutrient content from the laboratory analysis and the individual crop requirements.

- Calibrate your spreader so that proper amounts of organic material are applied and the spreader settings should be adjusted so that the spread pattern is uniform.

\section{Things to Avoid - Potential Pitfalls}

- Avoid sending samples to the laboratory over the weekend or over the holidays.

- Do not apply excessive amounts of organic fertilizer materials since excessive nutrients would be released, possibly leading to contamination of water sources.

- Do not apply large amounts of organic materials to soil to build up organic matter content of soil. This might also result in application of large amounts of $\mathrm{N}$ which could leach.

\section{Other Considerations}

- Organic fertilizers supply essential plant nutrients and serve as a soil amendment by adding organic matter.

- Organic materials increase the moisture holding capacity of sandy soils and improve lateral water movement, thus improving irrigation efficiency.

- Plants that are grown in soils with high organic matter are often damaged less by nematodes than are plants in soil of low organic matter content.

- Poultry manure has long been recognized as one of the most desirable of the natural fertilizers because of its relatively high nitrogen content.

- In areas where phosphorus movement off-site can lead to eutrophication of surface waters, phosphorus rather than nitrogen may be the factor determining application rate of an organic fertilizer material such as animal manure.

\section{Additional Readings}

Cage Layer Manure: An Important Resource for Land Use, PS-9, Fla. Coop. Ext. Ser., IFAS, Univ. of Fla. http://edis.ifas.ufl.edu/PS005

Poultry Manure as a Fertilizer, PS-1, Fla. Coop. Ext. Ser., IFAS, Univ. of Fla. http://edis.ifas.ufl.edu/AA205

Soil Organic Matter, Green Manures and Cover Crops for Nematode Management, SS-ENY-918, Fla. Coop. Ext. Ser., IFAS, Univ. of Fla. http://edis.ifas.ufl.edu/VH037

Utilization of Organic Wastes in Florida Agriculture, SS-AGR-166, Fla. Coop. Ext. Ser., IFAS, Univ. of Fla. http://edis.ifas.ufl.edu/AG113

Soil and Fertilizer Management for Vegetable Production in Florida, HS711, Fla. Coop. Ext. Ser., IFAS, Univ. of Fla. http://edis.ifas.ufl.edu/CV101

University of Florida, North Florida Research and Education Center-Suwannee Valley website, http://nfrec-sv.ifas.ufl.edu/ 
Sampling guide from University of Florida,

North Florida Research and Education

Center-Suwannee Valley Animal Waste Testing

Laboratory, USDA-NRCS Phosphorus. 